\section{REMARKABLE PLANTS}

IV.-The BLUE GUM TREe (Eucalyptus globulus, Labil.).

SO much attention has been directed during the last few years to the various remarkable virtues attributed to this tree, that an exaggerated idea of its value may exist in many minds. Sufficient has, however, been established on irrefragable authority to justify a brief account, in this series of papers, of the known properties and qualities of the Eucalyptus. We rely for a considerable proportion of our facts on a lecture delivered before the Royal Botanic Society of London in 1874 , by Prof. Bentley, and on the account of the tree in Bentley and Trimen's "Medicinal Plants," part 15, our illustration being also, to a considerable extent, copied from that in the latter work.

The genus Eucalyptus is a large one, numbering about r $5^{\circ}$ species, and belongs to the natural order Myrtaceæ, distinguished by the number of trees and shrubs included in it which yield aromatic properties. The species are all, with a few doubtful exceptions, natives of Australia or Tasmania, and are known in the Colonies as "gum-trees" and "stringy-bark trees." They are all evergreen trees, several of them of enormous height. The one we are describing, a native of Tasmania and temperate Australia, is perhaps the most gigantic of them all, not unfrequently attaining a height of upwards of 300 feet.

The leaves vary remarkably according to the age of the plant ; when it is young they are large, sessle, and opposite, of a bluish glaucous-white colour, and placed at right-angles to the branches on which they grow, while on older plants they are much narrower (as shown in the drawing), alternate, bluis green, and, by a twisting of the petiole, appear as if placed obliquely, or in the same plane as the branches, with their flat surfaces lateral. Th. flowers are large and not very unlike those of the myrtle, with a very large number of stamens, but differing in the

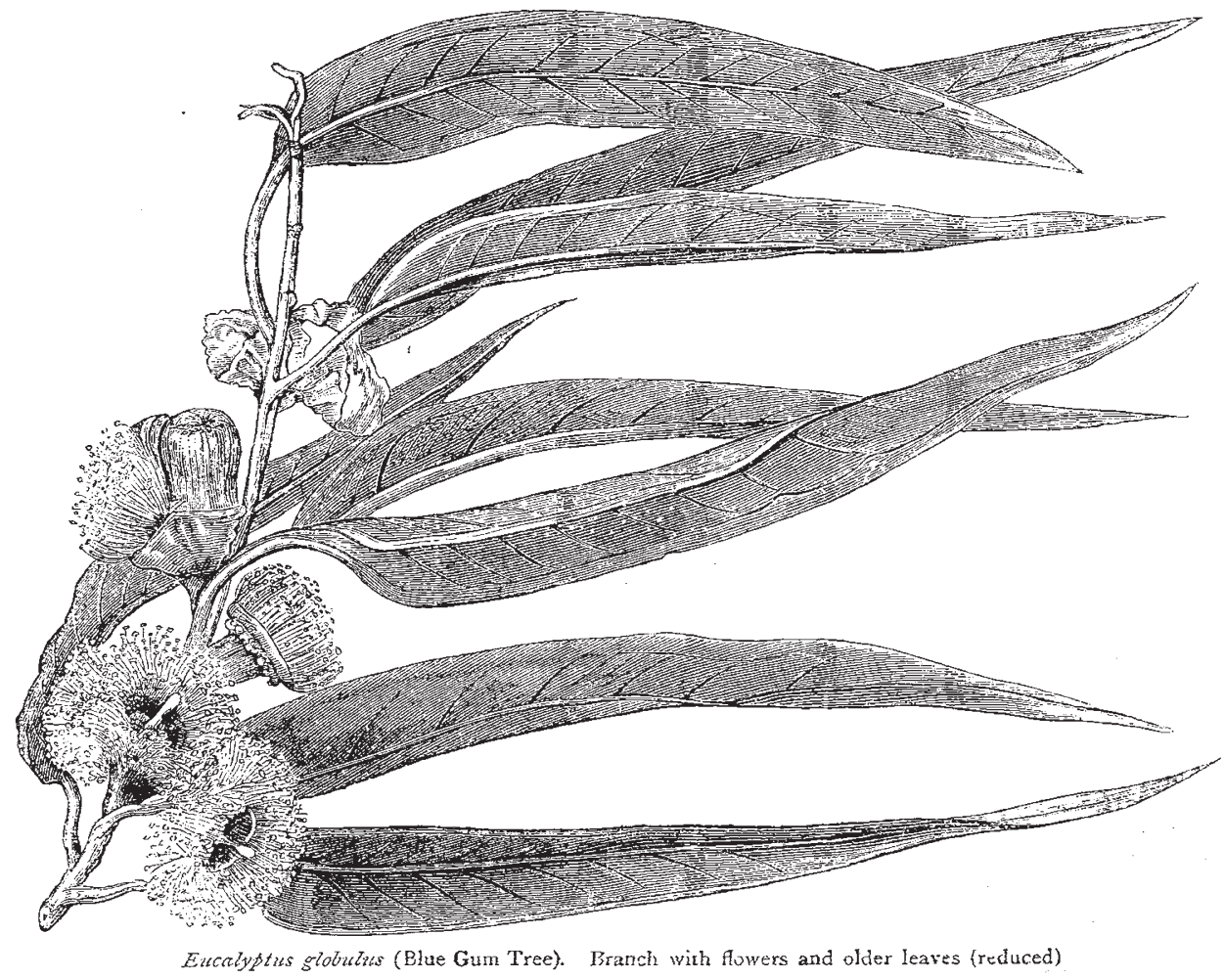

absence of a corolla, the limb of the calyx becoming detached when the flower opens in the form of a lid or "operculum."

The rapidity of the growth of this tree is one of its most remarkable and valuable features. Although not introduced into this country till the year $185^{6}$, and not perfectly hardy here, except perhaps in the extreme south-west, trees of a considerable size are not unfrequently seen. A specimen only two years old has flowered this year in the Economic House at the Regent's Park Botanic Gardens. In its native country it is stated that in a grove planted only sixteen years, the average height of the trees is seventy-two feet, and the girth of the stems six feet; while a tree ten years old presents the development of a well-grown oak of a century. In fifty years they are said to attain a height of from 160 to 200 feet, and the trunk a circumference of from 50 to 60 feet at the base. Even where the Eucalyptus is not indigenous, well-authenticated instances of a rapidity of genous, well authe record in favcurable climates. Mr. Thomas Hanbury states that near Mentone a seedling planted in March, 1869, was then three feet high ; in 1874 it had reached forty-eight feet, and the circumference of the trunk was three feet at three feet above the ground. In Algeria the growth is no less astonishingly rapid. The gigantic size of the trunk is combined with a peculiarity of growth which greatly adds to the value of the timber. It rarely sends out a branch till the stem is Ioo feet high, and Prof. Bentley states that planks have frequently been cut 160 feet long, twenty inches broad, and six inches thick. The timber is stated to be at the same time remarkable for its hardness and durability.

This rapid growth renders the Eucalyptus an invaluable tree for planting in countries where deforesting has been carried to so great an extent as to prejudicially dininish the rainfall; and it has now been more or less successfully cultivated for this purpose in France, Spain, Portugal, Greece, Italy, Corsica, Algeria, Egypt, St. Heltna, Palestine, the uplands of India; Natal, other parts of 
South Africa, Cuba, and various parts of North and South America. It has already been stated that it is not hardy in this country, a temperature below the freezing pointor even in some cases a little above it -appearing to kill it. Another useful quality of the tree is that, in consequence of its deciduous bark, it is not attacked by parasites. Baron von Mueller, the director of the Botanic Gardens at Melbourne, states that the ashes of the wood of this and of other species of Eucaiyptus contain a very large proportion of potash, in some cases as much as twenty-one per cent.

The medicinal properties of the Eucalyptus globulus are due to the presence, so common in trees and shrubs belonging to the Myrtaceæ, of a volatile oil, in various parts of the plant, but especially in the mature leaves. This oil may readily be obtained by distillation with water, is of a yellow colour when freshly distilled, and resinifies by exposure to the air. Its principal constituent was found by C'oëz to be a colourless liquid boiling at $347^{\circ} \mathrm{F}$., which $\mathrm{t}$ e regarded as analogous to camphor, and to which he gave the name Eucalyptol; more recent investigations have shown this to be a mixture of two substances, a terpene and a cymol, the essential oil containing other substances in addition to these. Older statements that the leaves of Eucalyptus contain, besides this essential oil, quinia or some other of the well-known cinchona alkaloids, have been shown, by the researches of Broughton, to be altogether without foundation.

The value of the leaves as a febrifuge, especially in cases of intermitient fever, has been attested by many medical practitioners, English, Italian, and French; and in Australia the leaves have long had a popular reputation in the treatment of fevers. They are best administered in the form of an alcoholic tincture, which is also useful as a stimulant and antispasmodic. As an external dressing for wounds it is stated by M. Gimbert that the balsamic nature of the leaves not only has a curative effect, but removes all the unpleasant odour. The oil is also used as a disinfectant and antiseptic.

But the point to which the most interest attaches in connection with the Eucalyptus is its alleged anti-malarial properties, in consequence of which it bas been called the "fever-destroying tree." On this subject Prof. Bentley says that "the evidence that has been adduced from Austrailia, the native country of the tree, and from all parts of the world where it has been introduced, and which are favourable to its growth, in testimony of its anti-malarial properties, is so strong that, allowing for exaggeration in some cases, it can scarcely be doubted that this tree does produce a most beneficial effect by destroying the fever-producing miasm of marshy districts; and that it should consequently be introduced into all countries and districts where the climatic influences are favourable for its development, and where such miasmatic emanations are to be found." Special interest attaches to the introduction of the blue gum tree into Italy for this purpose, and it is confidently hoped that by its means the problem may at length be solved of destroying the noxious malaria which has in recent times rendered the level country round Rome so unhealthy in the summer season. The chief difficulty is with the occasional frosts to which Northern Italy is subject. Of a large number of trees planted at one time by the Roman Railway Company along the line from Rome to Naples, only those in the neighbourhood of Naples survived the first winter. It is possible, however, that if they became establisined through a succession of mild winters, and attained a good size, they might then be able to resist slight fros's.

The mode in which the trees thus act in influencing the climate is open to somewhat more controversy. The popular idea is that the efficient cause is the odorous and antiseptic emanations from the leaves. It is quite likely that some influence is exerted in this way, but it seems most probable that the chief effect produced is by the action of the roots on the soil. This function of trees is often greatly overlooked. The effect of the planting of forests in decreasing the rainfall is frequently erroneously stated to be due to the attractive force of the trees on the moisture in the air, similar to that exerted by a range of mountains; but it is difficult to conceive that the small mass of the entire foliage of a forest can exert any appreciable influence in this direction. The mode in which trees mainly act is by their roots arresting the rainfall, which would otherwise escape by the natural drainage of the country; the combined forces of capillarity, osmose, and transpiration then cause the ascent through the tissues of the tree of the water thus arrested, and the larger portion is eventually given off into the air through the stomata of the leaves. In this way a forest tree will in a very short time give off into the air its own weight in water, which must eventually condense, and be again deposited as rain or dew. It is quite possible, however, that the effect of the planting of trees may be apparently the reverse of this in swampy countries where there is no natural drainage. The water then accumulates in the soil; and, if the country is bare of timber-trees and the sun powerful, a rapid decomposition takes place of the herbaceous vegetation, with the consequent emanation of malarial vapours. The effect of the planting of trees under such conditions will be to supply artificial drainage ; the accumulation of water in the soil and the consequent noxious effluvia will be diminished and finally prevented, and the atmosphere will be rendered, if not drier, at all events more wholesome. This is the mode in which it is hoped that the malarial fevers of the Campagna may ultimately succumb to the influence of the Eucalyptus. In no quarter of the world have the beneficial eiffects of the planting of this tree been more distinctly seen than in Algeria, where it has been carried on to a considerabie extent for some years, mainly through the exertions of private individuals, French and English, aided by the Government. All the good things that have been said about it are there found to have been realised.

A. W. B.

MANTEGAZZA ON THE RELA TIVE LENGTHS OF THE INDEX AND "RING" FINGERS

$T \mathrm{HE}$ curious and suggestive researches made about two years ago by Prof. Ecker, of Freiburg University, in the Breisgau, into the comparative lengths of the index and ring fingers, the results of which were embodied in an article contributed to this journal (vol. xiii. p. 8), entitled, "A new Palmistry," have, in the meantime, been further followed out by Prof. Mantegazza, of Florence. ${ }^{1}$

With the aid of another observer the Florentine professor has made several hundred observations, almost all upon Italians, the subjects being for the most part Romans, Tuscans, and natives of Lombardy. The results are classified in the following table:-

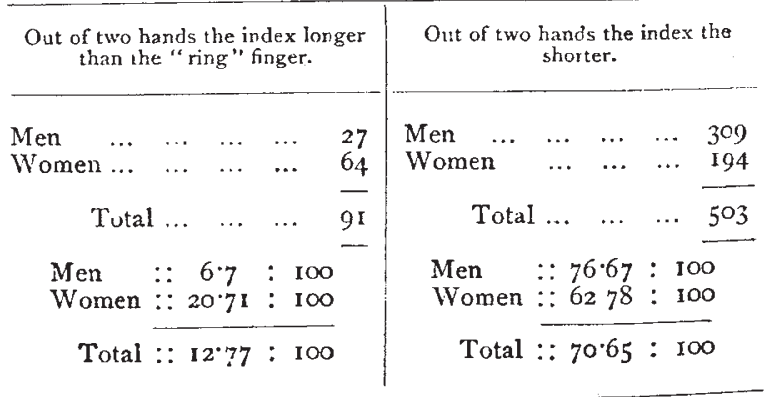
x "Della Lunghezza relativa dell' Indice e dell" Anulare della Mano tologia e la Eitnologia, vol. vii. p. 19 . Firenze, $8_{77}$. 